\title{
ASSESSMENT AND PRIORITIZING "INDICATORS SOCIAL AND LEGAL OF LEARNING CITY" IN THE AREAS OF YAZD CITY
}

\section{AVALIAÇÃO E PRIORIZAÇÃO DE "INDICADORES SOCIAIS E LEGAIS DA CIDADE DE APRENDIZAGEM" NAS ÁREAS DA CIDADE DE YAZD}

\author{
Mohammad Hossein Saraei ${ }^{1}$ \\ Shahabadin hajforoush ${ }^{2}$
}

\begin{abstract}
The concept of learning city emphasizes the transfer of knowledge and research. In fact, the learning city will strengthen the members of a community socially and legally and put them on the path to education. This research was conducted with the aim of evaluating and prioritizing social and legal indicators of the learning city in the area of Yazd city. The present study is based on the depth of the application-development study, in terms of the nature and method of descriptive-analytic and from the survey data gathering point. In this research, statistical methods of Kolmogorov-Smirnov test, single sample T, Simple linear regression, and W. Kendall have been used. The findings show that the distribution of data is normal, and the status of the variables examined by experts and experts in the most areas of the city of Yazd is undesirable. There is a significant relationship between social and legal index and independent variables in Yazd city. Overall, it was concluded that social and legal indexes in 2 area with the highest average rank in the first and the 6 area with the lowest average rank are in the last category. This prioritization reflects the fact that priority is given to programs in areas 6 of social and legal development of the learner's city in Yazd. At the end of the article, the discussion about the importance of knowledge of the word learning in the city has been addressed and some strategies have been presented to study the area of study in relation to social and legal indicators of the learning city.
\end{abstract}

Keywords: Legal and Social Indicators, Learning Organization, Learning Community, Learning City, Yazd City.

\section{Resumo}

O conceito de cidade de aprendizagem enfatiza a transferência de conhecimento e pesquisa. De fato, a cidade de aprendizagem fortalecerá social e legalmente os membros de uma comunidade e os colocará no caminho da educação. Esta pesquisa foi realizada com o objetivo de avaliar e priorizar indicadores sociais e legais da cidade de aprendizagem na área da cidade de Yazd. O presente estudo baseia-se na profundidade do estudo de desenvolvimento de aplicações, em termos da natureza e método da análise descritivo-analítica e do ponto de coleta de dados da pesquisa. Nesta pesquisa, foram utilizados métodos estatísticos do teste de Kolmogorov-Smirnov, amostra única $T$, regressão linear simples e W. Kendall. Os resultados mostram que a distribuição de dados é normal, e o status das variáveis examinadas por

\footnotetext{
1 Associate Professor of Geography and Urban Planning, Yazd University, Iran. E-mail: msaraei57@gmail.com.

2 Student Geography and Urban Planning, Yazd University, Iran. E-mail: shahabodinhajforoosh@gmail.com
} 
especialistas e especialistas na maioria das áreas da cidade de Yazd é indesejável. Existe uma relação significativa entre o índice social e legal e as variáveis independentes na cidade de Yazd. No geral, concluiu-se que os índices sociais e legais em 2 áreas com a maior classificação média na primeira e a 6 área com a classificação média mais baixa estão na última categoria. Esta priorização reflete o fato de que a prioridade é dada aos programas nas áreas 6 de desenvolvimento social e legal da cidade do aluno em Yazd. Ao final do artigo, abordou-se a discussão sobre a importância do conhecimento da palavra aprendizagem na cidade e algumas estratégias foram apresentadas para estudar a área de estudo em relação aos indicadores sociais e legais da cidade de aprendizagem.

Palavras-chave: Indicadores Legais e Sociais, Organização de Aprendizagem, Comunidade de Aprendizagem, Cidade de Aprendizagem, Cidade de Yazd.

\section{INTRODUCTION}

In the present age, learning is a key to survival and sustainability. The life of humans depends to a great extent on the various knowledge and skills they obtain. The more knowledge and skills acquired and optimized at the time, the greater the power of adaptation of humans to the changing environment (Abbasi et al., 2012: 54). Also, individuals have different ways of learning as they are individually different. Their strengths and preferences are in the way they absorb and process information (Truong, 2016: 1188).

In fact, the city is a small, large-scale, collective-based field that includes unpredictable potentials for building knowledge, making it accessible and expanding. The city can be a powerful tool for educating puberty and responsibility, collective life and citizenship, planning and valuing life, capacity for cooperation in the places and times available. Learning cities are the product of the development of innovative structures and processes, so that the resources of learning of all sectors of society (urban, economic, educational, general and voluntary) can be mobilized (Maleki Avaresin and Faraji, 2015). Thus, the concept of learner communities is drawn to the broad body of ideas related to learning and sociology (Kilpatrick, 2003: 9).

Globalization and economists, the growth of information technology, the transformation of the business world, the influence of consumerism, the advent of knowledge and learning as major assets, the changing roles and expectations of employees, the diversity and mobility of the workforce, rapid change and rioting are among the factors that create the learning city (Safania, 2015: 37), which emphasizes the necessity and importance of paying attention to the discussions of the learning city, especially in the city of Yazd. Therefore, the 
goals of building learning cities are to respond to rapid changes and different types of challenges and uncertainties arising from globalization and social and legal issues.

The explanation of the position of each of the main elements of the formation of the learning city in Yazd is an issue that can be carefully considered. In this regard, the main objective of the present research is to analyze the status of Yazd areas in terms of social and legal indicators, learning city and prioritize it and try to study these indicators of the learning city in the regions of Yazd to create a learning city and strengthen the lifelong learning system for citizens. Advancement of sustainable knowledge according to available capacities. The logic of this article focuses on the social and legal learning base in Yazd. Accordingly, the main question of this study is that what is the status of social and legal indicators of the learning city in the areas of Yazd?

In external research, Olivus et al. (2016) concluded in an article entitled The relationship between learning styles and motivation to transfer learning in the professional education program. According to the significant results ( $\mathrm{Sig}=0 / 002)$, there was a significant relationship between learning styles and professional education programs. In a study entitled Sustainable Development of the Learner's Town, Jucevicience (2010) concluded that a learning city is a complex social structure. Its development means empowering learning at all levels of the city (residents and their families, organizations and urban management through networks). Hamilton (2010) concluded in a study entitled Learning City that learning cities in the UK should increase investment, create a network of learning cities, collaborate and collaborate among different organizations, education, business, local government, private sector, etc. To be In a study titled "Learning cities", Di Sivoa and Ladianaa (2010) concluded that learning society is a social one in which learning is extensive and lifelong. Activating the lifelong learning process as a fundamental strategy is to create conditions for improvement from the social, economic, political, and cultural perspective, as well as to improve the quality of life of citizens. Faris (2006) concluded that learning is often measurable and valid. It is also a historical process because successive generations have collaborated on the gradual collection and transfer of our knowledge, skills, attitudes and values. Langworth and Kelly (2006) concluded that learning cities in Canada should increase awareness of lifelong learning, the highest literacy rates, increased engagement of citizens, strong partnerships between business and education, increased funding and resources to facilitate Stay in lifelong learning and more.

In domestic research, the literature and literature on lifelong learning and learning cities in our country can only be quoted in four articles: 
Sarvar et al. (2016) concluded in an article entitled "Investigating the Relationship Between the Factors Affecting the Formation of the Learning city" (Case Study: Bonab City) that between the characteristics of the learning city and the educational centers (schools, academic and applied centers of universities) There is a direct and significant relationship between large and small organizations and municipalities as the learning organization in Bonab city. Hosseini and Gholipour (2015) in an article entitled "Analysis of Indicators of Islamic Learning Town and its Relationship with Sustainable Urban Development" (Case Study: Rasht city), concluded that planning to improve the Indicators of the Islamic learning city in Rasht has achieved sustainable urban development And through this way, the city of knowledge will make Rasht more central. Manafi and Esmail Pour (2015) in an article titled "Income on the Concept of the Learning city", concluded that citizens' educational and learning programs should be designed in accordance with the city's mission, in order to ultimately fulfill the mission and mission of the city. Bayat et al. (2012) in a paper titled "Identifying the Factors Influencing the Creation of a Learning Town in Tehran Municipality 6" examined the concept of the learning city and identified the factors influencing the formation of this concept in the 6th municipality of Tehran. The findings of the study indicate the status of the 6th district of the municipality Tehran is based on the dimensions of the learning city, according to experts.

The results of the research show that learning cities are a fundamental strategy for creating conditions for improvement from the social, economic, political and cultural point of view. Also, according to the social and legal index of research, in these cities, the variables improving the quality of life of citizens increased Citizen Engagement, the highest rates of literacy, strong partnership between trade and education.

\section{LEARNING CITY}

Today's city is actually the result of the accumulation of experiences and learning about living in the city, its requirements and needs throughout its history of urbanization (Kirkabadi and Alipour, 2011). In the knowledge world, local and regional managers understand that a more successful future depends on the development of their human and social capital and issues such as the learning city are considered by urban managers and policymakers (Gertler and Wolf, 2004: 50). A learning city unites all learning providers to meet the needs and aspirations of its citizens. Through the local resources they bring together, learner cities can find local solutions to local challenges (Kearns et al, 1999). Also, a learning city involves a city or 
village that tries to learn how to adapt itself to the amazing world of change (Candy, 2003). so, if a learning city is to be considered, we will achieve remarkable results for a great city. It is worthwhile and is a very important help for better city governance (Echoes of the city, 2012).

\section{Results of learning cities}

Among the results of learning cities, it is possible to increase the connection between people's learning and reducing crime, reducing poverty, increasing success, increasing cooperation, increasing self-esteem and community stability; getting citizens informed of their rights; making it possible for citizens who are anywhere wherever they are And learn as much as they want (such as learning in shopping malls); developing citizens' ability to participate intellectually and responsibly in the political, economic, social and cultural life; acceptance of learning as a continuous activity throughout life; increasing abilities and personal and common values; and Teamwork; providing equal opportunities; Ray for minority groups, women, the disabled and others; understand the nature of learning and participation and develop local and global learning organizations can be noted (Longworth, 2006; Dekoulou \& Trivellas, 2015; Ly et al. 2017).

\section{Social and legal index}

Indicators are necessarily feedback mechanisms that help us to understand where we are, in which direction and how far away the target is. The social and legal index should provide a clear indication of the existence or absence of something and the identification of different behaviors in the area under our supervision (Javedan, 2010: 3).

\section{METHODOLOGY}

In this research, a survey method has been used for data collection. The present study is based on the nature and method of descriptive-analytic and depth of applied-development study. In this research, cluster sampling method is used. The process of extraction of indicators is done by fission analysis. To this end, a thorough review of topic literature, past research, and a survey of 30 experts, including professors and specialists in various trends, geography, urbanization, social sciences, ecology, law and urban management, and collectively have the 
same views of the same The social and legal variables of the learning city of Yazd city were extracted. The validity of the questionnaire (in the first part, the statistical characteristics of the questionnaires and in the second part, with regard to social and legal variables, were used in 8 questions and 5 Likert range options), using the views of the professors and experts in this area. Due to the specialized nature of the subject, the statistical society includes groups of experts and experts active in organizations related to the concept of the learning city of Yazd (including municipalities, schools, universities, companies, basij areas, organizations and libraries). Due to the fact that the exact number of the statistical population was not clear, the sample size was calculated using the personal estimation method. After calculating the required number of 320 people, it was calculated using a two-dimensional questionnaire in 8 districts of Yazd city (according to population size of each area and proportionate to the population) It was distributed and cited in the analysis. Cronbach's alpha has been used for reliability of the instruments. This coefficient tests the reliability and accuracy of the instrument. Accordingly, the Cronbach's alpha coefficient has a design questionnaire of 0/870 percent, which indicates the high reliability of the questionnaire questions and the internal correlation of the questions to measure the variables of the research. SPSS software was used for analyzing the collected indices. The Kolmogorov-Smirnov test, single sample T, Simple linear regression, and W. Kendall were used to analyze the collected indices.

According to table (1), the indicators and variables used in this research are indicated:

\section{Table 1: Indicators and variables used in the research}

\begin{tabular}{|l|l|}
\hline index & Variable \\
\hline \multirow{3}{*}{$\begin{array}{l}\text { Social and } \\
\text { legal }\end{array}$} & $\begin{array}{l}\text { A comprehensive and effective relationship between organizational components } \\
\text { as well as in relation to other organizations }\end{array}$ \\
\cline { 2 - 2 } & $\begin{array}{l}\text { Participation in local and regional activities among urban authorities } \\
\text { The city-based cooperation framework is supported by stakeholders who support } \\
\text { learning strategies }\end{array}$ \\
& $\begin{array}{l}\text { Teamwork and co-operation among urban organizations } \\
\text { Democratic Thought and Citizen Participation }\end{array}$ \\
\hline & $\begin{array}{l}\text { Active learning programs to increase participation in local and regional activities } \\
\text { Lawmaking in organizations }\end{array}$ \\
\hline & Responsibility in organizations \\
\hline
\end{tabular}

Source: The authors, adapted from Sarver et al., 2017; Ghiyoswand and Abdul Shah, 2016; olivus et al., 2016; Shams et al., 2015; Balangao, 2013; Yang, 2010; Bouton, 2007; Don Clark, 2000; Schwartz et al., 2002; www.fa.irunesco.org; www.longlearn.org.uk; www.muhc.ir. 


\section{Range of study}

Yazd province is located north of Semnan and Khorasan Razavi provinces, south of Kerman province, east to south Khorasan province and west to Isfahan province, and is located in the middle of Iran's inner plateau. Also, the city of Yazd, with a width of 99/5 km and a latitude of 2952 to $3327^{\prime}$ north and longitude, is $5637^{\prime}$ to $5255^{\prime}$ east, and has three regions and eight urban areas (Yazd city governor, 1396). According to the latest census of population and housing in 1995, the population of Yazd totals 656/447, of which 195 thousand and 134 households live (Iran's Statistics Center, 2017).

\section{RESULTS}

\section{Descriptive findings}

In the study population, 40/7 percent of respondents were in the age group of 20-30 years, 51/9 percent in the age group of 30-40 years, 3/7 percent in the age group of 40-50 years and $3 / 7$ percent in the age group of more than 50 years old. Of 320 respondents, 85/7 percent were male and 14/3 percent were female and 74/3 percent were married and 25/7 percent were single. Of these, 44/4 percent of the respondents had a bachelor's degree, 51/9 percent had undergraduate education and 3/7 percent had doctoral degrees. This information indicates that respondents in the current research questionnaire have a relatively high level of education.

\section{Data analysis}

In this research, in order to evaluate the social and legal index of the learner's city in the areas of Yazd, four basic steps have been taken:

Stage One: In this research, Kolmogorov-Smirnov test is used to determine the consistency of empirical data obtained from a questionnaire with selected statistical distributions. In this test, if the meaningful value is less than $0 / 05$, then the nonparametric tests should be used and the data is not normal. Taking into account the results of the KolmogorovSmirnov test, Table 2 confirms the normality of this research data. 
Table 2. The results of Kolmogorov-Smirnov test from the social and legal index of the learning city in the regions of Yazd

\begin{tabular}{|c|c|c|c|c|}
\hline Variable & area & $\begin{array}{l}\text { data } \\
\text { Distribute }\end{array}$ & $\begin{array}{l}\text { Kolmogorov- } \\
\text { Smirnov }\end{array}$ & $\begin{array}{l}\text { Sig. (2- } \\
\text { tailed) }\end{array}$ \\
\hline \multirow{8}{*}{$\begin{array}{l}\text { A comprehensive and effective relationship } \\
\text { between organizational components as well as } \\
\text { in relation to other organizations }\end{array}$} & 1 & normal & $271 / 0$ & $894 / 0$ \\
\hline & 2 & normal & $773 / 0$ & $557 / 0$ \\
\hline & 3 & normal & $697 / 0$ & $746 / 0$ \\
\hline & 4 & normal & $403 / 0$ & $992 / 0$ \\
\hline & 5 & normal & $671 / 0$ & $759 / 0$ \\
\hline & 6 & normal & $619 / 0$ & $841 / 0$ \\
\hline & 7 & normal & $367 / 0$ & $997 / 0$ \\
\hline & 8 & normal & $417 / 0$ & $882 / 0$ \\
\hline \multirow{8}{*}{$\begin{array}{l}\text { Participation in local and regional activities } \\
\text { among urban authorities }\end{array}$} & 1 & normal & $371 / 0$ & $996 / 0$ \\
\hline & 2 & normal & $525 / 0$ & $840 / 0$ \\
\hline & 3 & normal & $669 / 0$ & $764 / 0$ \\
\hline & 4 & normal & $677 / 0$ & $756 / 0$ \\
\hline & 5 & normal & $661 / 0$ & $769 / 0$ \\
\hline & 6 & normal & $542 / 0$ & $617 / 0$ \\
\hline & 7 & normal & $369 / 0$ & $996 / 0$ \\
\hline & 8 & normal & $918 / 0$ & $272 / 0$ \\
\hline \multirow{8}{*}{$\begin{array}{l}\text { The city-based cooperation framework is } \\
\text { supported by stakeholders who support } \\
\text { learning strategies }\end{array}$} & 1 & normal & $389 / 0$ & $981 / 0$ \\
\hline & 2 & normal & $525 / 0$ & $944 / 0$ \\
\hline & 3 & normal & $651 / 0$ & $780 / 0$ \\
\hline & 4 & normal & $661 / 0$ & $769 / 0$ \\
\hline & 5 & normal & $669 / 0$ & $764 / 0$ \\
\hline & 6 & normal & $506 / 0$ & $960 / 0$ \\
\hline & 7 & normal & $360 / 0$ & $989 / 0$ \\
\hline & 8 & normal & $711 / 0$ & $688 / 0$ \\
\hline \multirow{8}{*}{$\begin{array}{l}\text { Teamwork and co-operation among urban } \\
\text { organizations }\end{array}$} & 1 & normal & $299 / 0$ & $891 / 0$ \\
\hline & 2 & normal & $575 / 0$ & $890 / 0$ \\
\hline & 3 & normal & $567 / 0$ & $866 / 0$ \\
\hline & 4 & normal & $468 / 0$ & $795 / 0$ \\
\hline & 5 & normal & $467 / 0$ & $796 / 0$ \\
\hline & 6 & normal & $683 / 0$ & $517 / 0$ \\
\hline & 7 & normal & $368 / 0$ & $999 / 0$ \\
\hline & 8 & normal & $816 / 0$ & $519 / 0$ \\
\hline \multirow{8}{*}{ Democratic Thought and Citizen Participation } & 1 & normal & $369 / 0$ & $968 / 0$ \\
\hline & 2 & normal & $301 / 0$ & $645 / 0$ \\
\hline & 3 & normal & $651 / 0$ & $801 / 0$ \\
\hline & 4 & normal & $697 / 0$ & $769 / 0$ \\
\hline & 5 & normal & $667 / 0$ & $756 / 0$ \\
\hline & 6 & normal & $568 / 0$ & $905 / 0$ \\
\hline & 7 & normal & $468 / 0$ & $799 / 0$ \\
\hline & 8 & normal & $997 / 0$ & $272 / 0$ \\
\hline \multirow[b]{2}{*}{ Active learning programs to increase } & 1 & normal & $377 / 0$ & $993 / 0$ \\
\hline & 2 & normal & $529 / 0$ & $940 / 0$ \\
\hline
\end{tabular}




\begin{tabular}{|l|l|l|l|l|}
\hline participation in local and regional activities & 3 & normal & $659 / 0$ & $780 / 0$ \\
\hline & 4 & normal & $656 / 0$ & $765 / 0$ \\
\hline & 5 & normal & $303 / 0$ & $999 / 0$ \\
\hline & 6 & normal & $873 / 0$ & $447 / 0$ \\
\hline & 7 & normal & $368 / 0$ & $999 / 0$ \\
\hline \multirow{5}{*}{ Lawmaking in organizations } & 8 & normal & $511 / 0$ & $955 / 0$ \\
\hline & 1 & normal & $388 / 0$ & 1 \\
\hline & 2 & normal & $565 / 0$ & $805 / 0$ \\
\hline \multirow{5}{*}{ Responsibility in organizations } & 3 & normal & $718 / 0$ & $719 / 0$ \\
\hline & 4 & normal & $669 / 0$ & $764 / 0$ \\
\hline 5 & normal & $661 / 0$ & $779 / 0$ \\
\hline & 6 & normal & $884 / 0$ & $416 / 0$ \\
\hline & 7 & normal & $457 / 0$ & $897 / 0$ \\
\hline & 8 & normal & $482 / 0$ & $773 / 0$ \\
\hline & 1 & normal & $420 / 0$ & $890 / 0$ \\
\hline 2 & normal & $367 / 0$ & $925 / 0$ \\
\hline & 3 & normal & $431 / 0$ & $929 / 0$ \\
\hline & 4 & normal & $308 / 0$ & 1 \\
\hline 5 & normal & $561 / 0$ & $669 / 0$ \\
\hline & 6 & normal & $502 / 0$ & $961 / 0$ \\
\hline & 7 & normal & $368 / 0$ & $999 / 0$ \\
\hline & 8 & normal & $759 / 0$ & $512 / 0$ \\
\hline
\end{tabular}

Source: Writers, 2017

Second step: Considering that the distribution of data in Kolmogorov-Smirnov test was normal and there was no significant difference between them, a single-sample T test was used. The results of single-sample t-test for research variables, as shown in Table (3) The variables examined by experts and experts in most areas of the city of Yazd are undesirable. Thus, in the overall and effective relationship between the components of the organization and also with other organizations, the areas of Yazd, the lowest mean for the 6th area (negative T), the significance level below 0/05 indicates that the mean of the variable with the comparison number (3) has a significant difference, and the highest mean is for area $5(T=0)$. In the variable of participation in local and regional activities among urban authorities, the lowest mean for area 6 (negative $T$ ), with a significant level below $0 / 05$, indicates that the mean of the variable is comparable with the number ( 3 ) and the highest mean is related to areas 5 and $7(T=0)$. In the variable of the urban cooperation framework by stakeholders who support learning strategies, the lowest mean for area 6 (negative T), with a significant level below 0/05, indicates that the mean of the variable is comparable with the number (3) and the highest the mean for region 2 is (negative T). In the group work and co-operation variable among urban organizations, the lowest mean for area 5 (negative T), with a meaningful level below 0/05, shows that the mean 
of the variable is comparable with the number (3) and the highest mean for the area $2(T=0)$. In the variable of democratic thinking and citizen participation, the lowest mean for area 6 (negative T), with a significant level below $0 / 05$, shows that the mean of the variable is comparable with the number (3) and the highest mean is for area $2(T=0)$. In the active learning program variable, to increase participation in local and regional activities, the lowest mean for area 6 (negative T), with a significant level below 0/05, indicates that the mean of the variable is comparable with the number ( 3 ) and the highest mean Related to area $7(T=0)$. In the variable, the legalism in organizations is the lowest mean for region 1 (negative T) and the highest mean for area 5 (Positive T), with a significant level below 0/05 for both regions, shows that the mean of the variable with the comparison number (3) has a significant difference. In the liability variable in organizations, the lowest mean for area 5 (negative T), with a significant level below 0/05, shows that the mean of the variables has a significant difference with the number (3) and the highest mean is related to area $7(T=0)$.

Table 3. T-test results are a single sample of the social and legal index of the learning city in the regions of Yazd

\begin{tabular}{|c|c|c|c|c|c|c|}
\hline Variable & area & Mean & $\begin{array}{c}\text { Std. } \\
\text { Deviation }\end{array}$ & $\begin{array}{l}\text { Test } \\
\text { value }\end{array}$ & $\mathrm{T}$ & $\begin{array}{l}\text { Sig. }(2- \\
\text { tailed) }\end{array}$ \\
\hline \multirow{8}{*}{$\begin{array}{c}\text { A comprehensive and effective } \\
\text { relationship between organizational } \\
\text { components as well as in relation to } \\
\text { other organizations }\end{array}$} & 1 & $51 / 2$ & $577 / 0$ & 3 & 732/1- & $182 / 0$ \\
\hline & 2 & $76 / 2$ & $258 / 1$ & 3 & 397/0- & $718 / 0$ \\
\hline & 3 & $68 / 2$ & $155 / 1$ & 3 & $500 / 0-$ & $667 / 0$ \\
\hline & 4 & $33 / 2$ & $155 / 1$ & 3 & 1- & $423 / 0$ \\
\hline & 5 & 3 & 1 & 3 & 0 & 1 \\
\hline & 6 & $53 / 1$ & $577 / 0$ & 3 & 196/5- & $014 / 0$ \\
\hline & 7 & $52 / 2$ & $707 / 0$ & 3 & 1- & $500 / 0$ \\
\hline & 8 & $69 / 2$ & $033 / 1$ & 3 & 791/0- & $465 / 0$ \\
\hline \multirow{8}{*}{$\begin{array}{l}\text { Participation in local and regional } \\
\text { activities among urban authorities }\end{array}$} & 1 & 2 & $816 / 0$ & 3 & $449 / 2$ & $092 / 0$ \\
\hline & 2 & $49 / 2$ & $915 / 1$ & 3 & $522 / 0$ & $638 / 0$ \\
\hline & 3 & $32 / 2$ & $577 / 0$ & 3 & $2-$ & $184 / 0$ \\
\hline & 4 & 2 & 1 & 3 & 732/1- & $225 / 0$ \\
\hline & 5 & 3 & $732 / 1$ & 3 & 0 & 1 \\
\hline & 6 & $24 / 1$ & $500 / 0$ & 3 & 7- & $006 / 0$ \\
\hline & 7 & 3 & 0 & 3 & 0 & 1 \\
\hline & 8 & $38 / 2$ & $211 / 1$ & 3 & $348 / 1-$ & $235 / 0$ \\
\hline \multirow{6}{*}{$\begin{array}{l}\text { The city-based cooperation framework } \\
\text { is supported by stakeholders who } \\
\text { support learning strategies }\end{array}$} & 1 & $20 / 2$ & $500 / 0$ & 3 & 3- & $058 / 0$ \\
\hline & 2 & $77 / 2$ & $957 / 0$ & 3 & $522 / 0-$ & $638 / 0$ \\
\hline & 3 & $64 / 2$ & $577 / 0$ & 3 & 1- & $423 / 0$ \\
\hline & 4 & $61 / 1$ & $155 / 1$ & 3 & $2-$ & $184 / 0$ \\
\hline & 5 & $64 / 2$ & $577 / 0$ & 3 & $1-$ & $423 / 0$ \\
\hline & 6 & $55 / 1$ & $500 / 0$ & 3 & 196/5- & $014 / 0$ \\
\hline
\end{tabular}




\begin{tabular}{|c|c|c|c|c|c|c|}
\hline & 7 & $53 / 2$ & $707 / 0$ & 3 & 1- & $500 / 0$ \\
\hline & 8 & $68 / 2$ & 033/1 & 3 & 791/0- & $465 / 0$ \\
\hline \multirow{8}{*}{$\begin{array}{c}\text { Teamwork and co-operation among } \\
\text { urban organizations }\end{array}$} & 1 & $25 / 2$ & $500 / 0$ & 3 & 3- & 058/0 \\
\hline & 2 & 3 & $826 / 0$ & 3 & 0 & 1 \\
\hline & 3 & $64 / 2$ & $577 / 0$ & 3 & 1- & $423 / 0$ \\
\hline & 4 & $33 / 2$ & $528 / 1$ & 3 & $756 / 0-$ & $529 / 0$ \\
\hline & 5 & $67 / 1$ & $155 / 1$ & 3 & 2- & $044 / 0$ \\
\hline & 6 & $1 / 2$ & $816 / 0$ & 3 & $449 / 2-$ & $092 / 0$ \\
\hline & 7 & $58 / 2$ & $707 / 0$ & 3 & 1- & $500 / 0$ \\
\hline & 8 & $5 / 2$ & $225 / 1$ & 3 & 1- & $363 / 0$ \\
\hline \multirow{8}{*}{$\begin{array}{c}\text { Democratic Thought and Citizen } \\
\text { Participation }\end{array}$} & 1 & $75 / 1$ & $957 / 0$ & 3 & $611 / 2-$ & $080 / 0$ \\
\hline & 2 & 3 & $155 / 1$ & 3 & 0 & 1 \\
\hline & 3 & 2 & 1 & 3 & 732/1- & $235 / 0$ \\
\hline & 4 & 2 & 1 & 3 & 732/1- & $235 / 0$ \\
\hline & 5 & 2 & 1 & 3 & $732 / 1-$ & $235 / 0$ \\
\hline & 6 & $25 / 1$ & $500 / 0$ & 3 & 7- & $006 / 0$ \\
\hline & 7 & $5 / 2$ & $807 / 0$ & 3 & 1- & $500 / 0$ \\
\hline & 8 & $17 / 2$ & $983 / 0$ & 3 & $076 / 2-$ & $093 / 0$ \\
\hline \multirow{8}{*}{$\begin{array}{c}\text { Active learning programs to increase } \\
\text { participation in local and regional } \\
\text { activities }\end{array}$} & 1 & $25 / 2$ & $500 / 0$ & 3 & $3-$ & 058/0 \\
\hline & 2 & $5 / 2$ & $577 / 0$ & 3 & $732 / 1-$ & $182 / 0$ \\
\hline & 3 & $65 / 2$ & $577 / 0$ & 3 & 1- & $423 / 0$ \\
\hline & 4 & $65 / 2$ & $577 / 0$ & 3 & 1- & $423 / 0$ \\
\hline & 5 & 2 & 1 & 3 & 732/1- & $235 / 0$ \\
\hline & 6 & $85 / 1$ & $657 / 0$ & 3 & 611/2- & 049/0 \\
\hline & 7 & 3 & 0 & 3 & 0 & 1 \\
\hline & 8 & $17 / 2$ & $753 / 0$ & 3 & $712 / 2-$ & $042 / 0$ \\
\hline \multirow{8}{*}{ Lawmaking in organizations } & 1 & $74 / 1$ & $500 / 0$ & 3 & 5- & $015 / 0$ \\
\hline & 2 & 3 & 414/1 & 3 & 0 & 1 \\
\hline & 3 & $33 / 2$ & $155 / 1$ & 3 & 756/0- & $529 / 0$ \\
\hline & 4 & $67 / 2$ & $577 / 0$ & 3 & 1- & $423 / 0$ \\
\hline & 5 & $33 / 4$ & $155 / 1$ & 3 & 2 & $034 / 0$ \\
\hline & 6 & $65 / 2$ & $291 / 1$ & 3 & $775 / 0-$ & $495 / 0$ \\
\hline & 7 & $55 / 2$ & $707 / 0$ & 3 & 1- & $500 / 0$ \\
\hline & 8 & $61 / 2$ & $211 / 1$ & 3 & 674/0- & $530 / 0$ \\
\hline \multirow{8}{*}{ Responsibility in organizations } & 1 & $76 / 2$ & $500 / 0$ & 3 & 1- & $391 / 0$ \\
\hline & 2 & $5 / 2$ & $291 / 0$ & 3 & 775/0- & $495 / 0$ \\
\hline & 3 & $77 / 2$ & $528 / 0$ & 3 & $378 / 0-$ & $742 / 0$ \\
\hline & 4 & $57 / 2$ & $155 / 1$ & 3 & $500 / 0-$ & $677 / 0$ \\
\hline & 5 & $33 / 1$ & $577 / 0$ & 3 & 5- & $038 / 0$ \\
\hline & 6 & $75 / 1$ & $957 / 0$ & 3 & 611/2- & $080 / 0$ \\
\hline & 7 & 3 & 0 & 3 & 0 & 1 \\
\hline & 8 & $52 / 2$ & $548 / 0$ & 3 & 236/2- & $076 / 0$ \\
\hline
\end{tabular}

Source: Writers, 2017

Stage Three: Given the fact that the distribution of data in the Kolmogorov-Smirnov test was normal, a simple linear regression (Model Summary) test was used. According to the results 
of a simple linear regression analysis (Table 4) Social and legal index with independent variables in Yazd city was investigated which shows that there is a significant relationship between social and legal index and independent variables in Yazd city.

Table 4. Results of Regression Model Summary between Social and Legal Indicators with Independent Variables of Yazd City

\begin{tabular}{|c|c|c|c|c|c|c|c|c|c|c|c|}
\hline \multirow[b]{2}{*}{$\begin{array}{l}\text { inde } \\
x\end{array}$} & \multirow[b]{2}{*}{$\begin{array}{l}\text { independ } \\
\text { ent } \\
\text { variables }\end{array}$} & \multirow[b]{2}{*}{$\begin{array}{c}\text { Durbi } \\
\text { n- } \\
\text { Wats } \\
\text { on }\end{array}$} & \multicolumn{5}{|c|}{ Change Statistics } & \multirow[b]{2}{*}{$\begin{array}{l}\text { Std. } \\
\text { Error of } \\
\text { the } \\
\text { Estimat } \\
\text { e }\end{array}$} & \multirow[b]{2}{*}{$\begin{array}{c}\text { Adjust } \\
\text { ed } R \\
\text { Square }\end{array}$} & \multirow[b]{2}{*}{$\begin{array}{l}\text { R } \\
\text { Squa } \\
\text { re }\end{array}$} & \multirow[b]{2}{*}{$R$} \\
\hline & & & $\begin{array}{l}\text { Sig. F } \\
\text { Chan } \\
\text { ge }\end{array}$ & $\begin{array}{l}\mathrm{df} \\
2\end{array}$ & $\begin{array}{c}d f \\
1\end{array}$ & $\begin{array}{c}\text { F } \\
\text { Chang } \\
\text { e }\end{array}$ & $\begin{array}{l}\text { R } \\
\text { Squar } \\
\text { e } \\
\text { Chan } \\
\text { ge }\end{array}$ & & & & \\
\hline \multirow{3}{*}{$\begin{array}{l}\text { soci } \\
\text { al } \\
\text { and } \\
\text { lega } \\
\text { I }\end{array}$} & education & $667 / 1$ & $\begin{array}{c}000 / \\
0\end{array}$ & 19 & 1 & $\begin{array}{c}544 / 1 \\
21\end{array}$ & $\begin{array}{c}715 / \\
0\end{array}$ & $\begin{array}{c}24653 / \\
14\end{array}$ & $909 / 0$ & $\begin{array}{c}715 / \\
0\end{array}$ & $\begin{array}{c}835 / \\
0\end{array}$ \\
\hline & Age & $867 / 1$ & $\begin{array}{c}001 / \\
0\end{array}$ & 19 & 1 & $\begin{array}{c}633 / 1 \\
23\end{array}$ & $\begin{array}{c}819 / \\
0\end{array}$ & $\begin{array}{c}95863 / \\
14\end{array}$ & $903 / 0$ & $\begin{array}{c}819 / \\
0\end{array}$ & $\begin{array}{c}825 / \\
0\end{array}$ \\
\hline & $\begin{array}{l}\text { marital } \\
\text { status }\end{array}$ & $759 / 1$ & $\begin{array}{c}004 / \\
0\end{array}$ & 19 & 1 & $\begin{array}{c}569 / 1 \\
11\end{array}$ & $\begin{array}{c}796 / \\
0\end{array}$ & $\begin{array}{c}73454 / \\
16\end{array}$ & $785 / 0$ & $\begin{array}{c}796 / \\
0\end{array}$ & $\begin{array}{c}721 / \\
0\end{array}$ \\
\hline
\end{tabular}

Thus, in the relation between regression between social and legal index and independent variable of education, $R$ is close to 1 , so there is a strong correlation between independent variable and dependent variable, and in Square $\mathrm{R}$, it shows that social and legal index can account for $71 / 5$ percent of variable variation it is a significant amount of education. The adjusted coefficient is 0/909 and is at a significant level of 0/000. Also, considering that the camera-Watson survey is between $1 / 5$ and $2 / 5$, it is possible to accept the independence of the observations and follow the test. And the relationship between regression between social and legal index and the independent variable of age, $\mathrm{R}$ is close to 1 , so there is a strong correlation between independent variable and dependent variable, and in square $\mathrm{R}$, it shows that social and legal index can account for 81/9 percent of the variables of age Explaining that it is actually significant. The adjusted coefficient is 0/903 and is at a significant level of 0/001. Also, considering that the camera-Watson survey is between $1 / 5$ and $2 / 5$, it is possible to accept the independence of the observations and follow the test. Also, the relationship between regression between social and legal indicators and the independent variable of marital status is $\mathrm{R}$ is close to 1 , so there is a strong correlation between independent variable and dependent variable and in square $R$, shows that social and legal index can be 79/6 percent of marital change Which is, in fact, significant. The value of the adjusted coefficient is $0 / 785$ and is at a 
significant level of 0/004. Also, considering that the camera-Watson survey is between $1 / 5$ and $2 / 5$, it is possible to accept the independence of the observations and follow the test.

Stage 4: Given that in this research, each item or question is considered as a variable, and for each of these variables, the average score must be calculated. And the difference between these variables should be checked by using the W. Kendal test. Further, prioritizing the areas of Yazd city with regard to social and legal variables and its index, the $\mathrm{W}$. Kendall test in Table (5) and (6) It is visible:

Table 5. Ranking of Yazd city areas according to social and legal indicators of the learning city in the test of W. Kendall

\begin{tabular}{|c|c|c|c|}
\hline Variable & area & $\begin{array}{l}\text { Mean } \\
\text { Rank }\end{array}$ & Ranking \\
\hline \multirow{8}{*}{$\begin{array}{l}\text { A comprehensive and effective relationship between organizational } \\
\text { components as well as in relation to other organizations }\end{array}$} & 1 & $45 / 3$ & 6 \\
\hline & 2 & $81 / 5$ & 2 \\
\hline & 3 & $29 / 4$ & 4 \\
\hline & 4 & $43 / 2$ & 7 \\
\hline & 5 & $1 / 7$ & 1 \\
\hline & 6 & $65 / 1$ & 8 \\
\hline & 7 & $72 / 3$ & 5 \\
\hline & 8 & $62 / 4$ & 3 \\
\hline Sig. (2-tailed) & \multicolumn{3}{|c|}{$03 / 0$} \\
\hline W. Kendal & \multicolumn{3}{|c|}{$245 / 0$} \\
\hline \multirow{8}{*}{$\begin{array}{l}\text { The city-based cooperation framework is supported by stakeholders } \\
\text { who support learning strategies }\end{array}$} & 1 & $33 / 3$ & 5 \\
\hline & 2 & $78 / 5$ & 2 \\
\hline & 3 & $09 / 4$ & 4 \\
\hline & 4 & $33 / 3$ & 5 \\
\hline & 5 & $14 / 6$ & 1 \\
\hline & 6 & $51 / 2$ & 6 \\
\hline & 7 & $14 / 6$ & 1 \\
\hline & 8 & $91 / 4$ & 3 \\
\hline Sig. (2-tailed) & \multicolumn{3}{|c|}{$04 / 0$} \\
\hline W. Kendal & \multicolumn{3}{|c|}{$291 / 0$} \\
\hline \multirow{8}{*}{$\begin{array}{l}\text { The city-based cooperation framework is supported by stakeholders } \\
\text { who support learning strategies }\end{array}$} & 1 & $09 / 3$ & 5 \\
\hline & 2 & $98 / 6$ & 1 \\
\hline & 3 & $22 / 5$ & 3 \\
\hline & 4 & $66 / 4$ & 6 \\
\hline & 5 & $22 / 5$ & 3 \\
\hline & 6 & $88 / 2$ & 7 \\
\hline & 7 & $79 / 3$ & 4 \\
\hline & 8 & $02 / 6$ & 2 \\
\hline Sig. (2-tailed) & \multicolumn{3}{|c|}{$001 / 0$} \\
\hline \multirow[t]{2}{*}{ W. Kendal } & \multicolumn{3}{|c|}{$159 / 0$} \\
\hline & 1 & 3 & 6 \\
\hline
\end{tabular}




\begin{tabular}{|c|c|c|c|}
\hline \multirow{7}{*}{ Teamwork and co-operation among urban organizations } & 2 & $01 / 6$ & 1 \\
\hline & 3 & $66 / 5$ & 2 \\
\hline & 4 & $25 / 3$ & 5 \\
\hline & 5 & $01 / 2$ & 8 \\
\hline & 6 & $84 / 2$ & 7 \\
\hline & 7 & $95 / 4$ & 3 \\
\hline & 8 & $44 / 4$ & 4 \\
\hline Sig. (2-tailed) & \multicolumn{3}{|c|}{$001 / 0$} \\
\hline W. Kendal & \multicolumn{3}{|c|}{$141 / 0$} \\
\hline \multirow{8}{*}{ Democratic Thought and Citizen Participation } & 1 & $25 / 2$ & 5 \\
\hline & 2 & $47 / 6$ & 1 \\
\hline & 3 & $93 / 3$ & 4 \\
\hline & 4 & $93 / 3$ & 4 \\
\hline & 5 & $93 / 3$ & 4 \\
\hline & 6 & $65 / 1$ & 6 \\
\hline & 7 & $45 / 5$ & 2 \\
\hline & 8 & $35 / 4$ & 3 \\
\hline Sig. (2-tailed) & \multicolumn{3}{|c|}{$002 / 0$} \\
\hline W. Kendal & \multicolumn{3}{|c|}{$201 / 0$} \\
\hline \multirow{8}{*}{$\begin{array}{l}\text { Active learning programs to increase participation in local and } \\
\text { regional activities }\end{array}$} & 1 & $35 / 3$ & 4 \\
\hline & 2 & $14 / 4$ & 3 \\
\hline & 3 & $99 / 4$ & 2 \\
\hline & 4 & $99 / 4$ & 2 \\
\hline & 5 & $66 / 2$ & 6 \\
\hline & 6 & $12 / 2$ & 7 \\
\hline & 7 & $21 / 6$ & 1 \\
\hline & 8 & $01 / 3$ & 5 \\
\hline Sig. (2-tailed) & \multicolumn{3}{|c|}{$000 / 0$} \\
\hline W. Kendal & \multicolumn{3}{|c|}{$080 / 0$} \\
\hline \multirow{8}{*}{ Lawmaking in organizations } & 1 & $88 / 2$ & 8 \\
\hline & 2 & $39 / 6$ & 2 \\
\hline & 3 & $12 / 3$ & 7 \\
\hline & 4 & $98 / 5$ & 3 \\
\hline & 5 & $54 / 7$ & 1 \\
\hline & 6 & $22 / 5$ & 4 \\
\hline & 7 & $32 / 3$ & 6 \\
\hline & 8 & $31 / 4$ & 5 \\
\hline Sig. (2-tailed) & \multicolumn{3}{|c|}{$003 / 0$} \\
\hline W. Kendal & \multicolumn{3}{|c|}{$187 / 0$} \\
\hline \multirow{8}{*}{ Responsibility in organizations } & 1 & $02 / 5$ & 3 \\
\hline & 2 & $29 / 3$ & 6 \\
\hline & 3 & $91 / 5$ & 2 \\
\hline & 4 & $33 / 4$ & 4 \\
\hline & 5 & $61 / 2$ & 8 \\
\hline & 6 & $01 / 3$ & 7 \\
\hline & 7 & $54 / 6$ & 1 \\
\hline & 8 & $87 / 3$ & 5 \\
\hline
\end{tabular}


Sig. (2-tailed)

W. Kendal
$002 / 0$

$123 / 0$

Source: Writers, 2017

As it is clear from the above table, the significance level in all variables is less than 0/05. As a result, the respondents' assessment of the social and legal indicators of the learning city in the regions of Yazd is not the same and can be ranked. Also, the W. Kendall value of all variables shows that there is less agreement among the respondents about the variables in question because the $\mathrm{W}$. Kendall value is close to 0 . Therefore, in the variable of the interrelated and effective relationship between the components of the organization and also in relation to other organizations, District 5 with an average rank of $7 / 1$ in the first and most important, and area 6 with an average of $1 / 65$ in the last rank and least important. In the variable of participation in local and regional activities among urban authorities, District 5 and 7 with a mean rank of 6/14 are in the first and most important and District 6 with an average of 2/51 in the last rank and least important. In the variable of the city-based cooperation framework by stakeholders who support learning strategies, District 2 with an average score of 6/98 is in the first and most important and District 6 with an average of $2 / 88$ in the last rank and least important. In the variable of group work and co-operation among urban organizations, District 2 with a mean rank of 6/01 is the first and most important and District 5 with a mean of 2/01 in the last rank and least important. In the variable of democratic thinking and citizen participation, District 2 with a mean rank of $6 / 47$ is in the first rank and is most important, and District 6 with an average of $1 / 65$ in the last rank and least important. In the variable of active learning programs to increase participation in local and regional activities, area 7 with an average rank of 6/21 is in the first and most important and area 6 with a mean of 2/12 in the last rank and least important. In the legalization variable in organizations, District 5 with a mean rank of 7/54 is in the first and most important and District 1 with an average of 2/88 in the last rank and least important. In the variable of accountability in organizations, area 7 with a mean rank of 6/54 is in the first and most important, and area 5 with an average of 2/61 in the last rank and least important. In sum, we conclude that the sum of the social and legal indexes of area 2 has the highest average rank in the first rank compared to other areas and has a high social and legal index, and area 6 has the lowest average rank in the last rank and the index Social and legal rights.

In the following, as shown in Table (6), the significance level in the social and legal index is 0/047. As a result, the meaningfulness below 0/05 indicates that the respondents' assessment 
of the social and legal index of the learning city in the areas of Yazd city is not the same and it can be Rate them. Also, the W. Kendal social and legal index shows that there is less agreement among respondents with regard to the index, because the value of $W$. Kendall is close to 0 . Therefore, area 2 with a mean score of $6 / 19$ is in the first rank and is most important. In the next level, area 7 is located at an average of $5 / 5$. In the next level 3 , the average rank is 5 , area 5 is $4 / 75$, area 8 is $4 / 38$, area 4 is $4 / 31$, area 1 is $3 / 38$, and the area is 6 , the average of $2 / 5$ is in the third to eighth place. Taken together, according to the results, it can be analyzed that the 2nd district of Yazd has a high social and legal index due to the existence of universities, institutes, colleges of teachers, and the 6th district of Yazd due to the location of the historical context and a large part of The worn out texture has a low social and legal index.

Accordingly, by creating the characteristics of a learning city in the regions of Yazd (especially in area 6, which is a low indicator of learning), there will be beneficial results for the city in the future, namely: increasing the relationship between learning organizations; increasing success; Increasing self-esteem and social stability; Getting citizens informed about their rights; Developing citizens' ability to participate intellectually and responsibly in political, economic, social and cultural life; Accept learning as a continuous activity throughout life; Increase capabilities; Personal values; Collaborative and teamwork; understanding local nature And the Global Learning and Participation and Development of Learning Organizations.

Table 6. Social and Legal Indicators of the Learning city in the W. kendal Test

\begin{tabular}{|c|c|c|c|}
\hline Variable & area & Mean Rank & Ranking \\
\hline \multirow{4}{*}{ social and legal } & 1 & $38 / 3$ & 7 \\
\cline { 2 - 4 } & 2 & $19 / 6$ & 1 \\
\cline { 2 - 4 } & 3 & 5 & 3 \\
\cline { 2 - 4 } & 4 & $31 / 4$ & 6 \\
\cline { 2 - 4 } & 6 & $75 / 4$ & 4 \\
\cline { 2 - 4 } & 7 & $5 / 2$ & 8 \\
\hline Sig. (2-tailed) & 8 & $38 / 4$ & 5 \\
\hline W. Kendal & \multicolumn{3}{|c|}{$047 / 0$} \\
\hline \multicolumn{2}{|c|}{ Source: Writers, 2017 } \\
\hline
\end{tabular}

\section{DISCUSSION \& CONCLUSIONS}

Since the realization of the goal of the learning city requires the participation of various city organizations that are involved in educating citizens, as well as the participation of all 
citizens in a coherent way. Accordingly, in this study, according to the social and legal indicators of the learning city in the areas of Yazd city, this index has been evaluated.

The results of this study showed that according to the Kolmogorov-Smirnov test, the distribution of data was normal and there was no significant difference between them. Based on the T-test of a single sample, the status of variables examined by experts and experts in most areas of the city of Yazd has been undesirable. This view means that the social and legal index of the learning city is not well-suited and should be managers, officials and policymakers in Yazd city. Take steps to raise the importance of this index. Also, based on simple model regression analysis, it was shown that there is a significant relationship between social and legal index and independent variables in Yazd city. It shows that social and legal index can affect 71/5 percent of variables of education, 81/9 percent of the variations in age and 79/6 percent of the variance of marital status changes, which is, in fact, significant. In the end, for the purpose of prioritizing the areas of Yazd city according to the social and legal index of the learning city, W. Kendall test was used. The significance of each of the variables in the regions of Yazd city was expressed from the sum of social and legal indexes of region 2 with the highest average rank The first level is more than other areas and has a high social and legal index, and area 6 has the lowest average rank and has a low social and legal index. This prioritization reflects the fact that in programs aimed at raising the social and legal indicators of the learning city in Yazd, priority is given to District 6 because it has a lower status and should take measures in this area.

The results of this study are in line with the evaluation and prioritization of "Social and Legal Indicators of the Learner's Town" in the areas of Yazd city with the results of other researchers referred to in the research section, so that in all researches this issue Confirm that in learning cities, learning at all levels of the city (residents and their families, organizations and urban management through networks) should be carried out so that the research has concluded that to reach the city of Yazd to the learning city There should be cooperation between managers, officials Considering that the realization of the goal of the learning city requires the participation of various city organizations that are involved in the training of citizens, as well as the participation of all citizens in a coherent way. In this research, municipality, university, education and small and small private organizations that are involved in the learning and socialization process of citizens have been taken into consideration, in order to realize the goal of the learning city, the role and responsibilities of each of the responsible organizations in the field of education Citizens are defined in the fulfillment of the mission of the learning city. In order to optimize the human potential of the city, it must be possible for 
group participation and collaboration among institutions, organizations and citizens. In this research, it is suggested that a council of the learning city council be composed of decisionmakers and officials of organizations involved in educating citizens. Regarding the presence of officials and representatives of different sectors of education, citizens will be provided with a comprehensive lifelong learning program for all citizens throughout their lives. In this council, the strategy and goals of the learning city of Yazd are defined. With regard to the capacities and facilities of each district in Yazd, the strategy and objectives of each area are identified in order to realize the goal of the learner city of Yazd. On the other hand, given the fact that the goal of defining the learning city as a component in the form of projects can be defined. The task of each area is specified in the project. Also, one of the goals of the learning city is to participate in global competition and economic growth at the local level, so realizing the learning city needs to be able to recognize the relative benefits of the city and to identify these abilities and use them at the regional and global levels. In this regard, there are some other solutions and suggestions in this area for studying the area of study and urban authorities towards the learning cities, which are as follows:

Holding a lesson for education groups for households with the goal of identifying the value of learning knowledge and creating interactions between citizens; collecting educational needs of neighborhoods and planning to estimate it; providing electronic infrastructures for creating a learning city network; holding lifelong learning workshops; encouraging various urban centers (universities, schools, Retirement center, elderly and children's homes, etc.) to move towards lifelong learning; constructive cooperation between all parts of the city to optimize, share resources and increase opportunities for educating and learning all citizens; $F$ the need to learn each citizen for personal development, career development and good family; encouraging the demand for learning through innovative information strategies, advertising events and effective use of the media; supporting the supply of learning by providing services, guidance, modern education and the possibility of effective use. New technology of education; Encouraging all citizens to participate through talents, skills and energy for environmental protection, social organization, schools and other peoples; creating wealth through entrepreneurship development and helping state and private sector organizations to become Learning organizations Create a sense of partnership among citizens to learn and Education about each other. 


\section{REFERENCES}

Abbasi, E., Rafiei, L., Farhadian, H., (2012). The study of the extent to which the organizations of the environmental NGO of Tehran have characteristics of a learning organization, Public Administration Quarterly, No. 4, Tehran University of Technology.

Balangao, k., (2013). Lifelong learning for all: inclision, prosperity and sustainability in cities, report of international conference of learning cities, Beiging, china , 6-9.

Bayat, S., Gholi, A., Pour Ezzat, A. A., (2012). Identification of effective factors in the formation of learning city in 6th district of Tehran municipality, Urban Management Quarterly, No. 31, Spring, pp. 139-156.

Bouton, M.E., (2007). Learning and behavior: A contemporary synthesis. Sunderland, MA: Sinauer Associates, Inc.

Candy, P., (2003). Life Long learning: critical, desirable or just a good idea. Address to Adult Learning Australia's Adult learners, week.

Dekoulou, P., Trivellas, P., (2015). Measuring the Impact of Learning Organization on Job Satisfaction and Individual Performance in Greek Advertising Sector, Journal: Procedia-Social and Behavioral Sciences, Vol. 175, 367-375.

Di Sivoa, M., Ladianaa, D., (2010). Towards a learning city the neighborhood lab and the lab net, Procedia Social and Behavioral Sciences, No.2, 5349- 5356.

Echoes of the city, (1391). Successful Design of Urban Public Space, Ahwaz Municipal Publication, D, No. 12.

Don Clark, Q., (2000). Learning styles. How we go from the unknown to the known. Http://learningstyles.com.

Emami, F., Nezami, A., Haji Rezaei, S., (2015). Conduct on the meaning and nature of learning cities and urban learning metrics, International Conference on Engineering Law and Law, April 2015.

Faris, R., (2006). Learning Cities: Lesson learned, in Support of Vancouver Learning city Initiative http://www.members.shaw.ca (accessed October 3, 2010).

Gertler, M.s., A.Wolf, D., (2004). Local Social Knowledge Management: Community Actors, Institution and Multilevel Governance in Regional Foresight Exercises, Futures, Vol.36, 45-65.

Ghiasvand, A., Abdolshah, F., (2015). Economic resilience indicators, Trend quarterly, year twenty-second, No. 71, Autumn, pp. 79-106.

Governor of Yazd, (2016). Yazd.

Hamilton, R., (2010). Learning Cities: The United Kingdom Experience. 
Hosseini, S. A., Gholipour, Y., (2015). Analysis of Indicators of Islamic Learner's City and its Relationship with Sustainable Urban Development (Case Study: Rasht City), National Conference on Architecture and Iranian-Islamic Urban Planning, May-May, pp. 1-15.

http:// www.fa.irunesco.org.

http://www.longlearn.org.uk

http://muhc.ir

Iran's Statistics Center, General Census of Infiltration and Housing, (2016). Yazd city.

Javedan, m., (2010). A Review on theConceptual and Strategic Framework of Social Sustainability Indicators, Social Development Group, No. 172, pp. 1-3.

Jucevicience, P., (2010). Sustainable Development of the Learning City, European Journal of education, vol. 45 No.3.

Karkeh Abadi, Z., Alipour, I., (2011). Knowledge Cities: Approaches, Experiences and Views, Azarakhsh Publications, Tehran.

Kearns, P., McDonald, R., Candy, P., Knight, S., Papadopoulos, G., (1999). Lifelong Learning, VET in the Learning Age: The challenge of Lifelong Learning For All, Volumes 1,2 and 3, NCVER. South Australia. Anta.

Kelly, C., (2006). Vancouver Learning City Executive Committee, Lifelong Learning Strategy for the City of Vancouver.

Kilpatrick, S., (2003). Margaret Barrett and Tammy Jones, Defining Learning Communities, CRLRA Discussion paper D1, University of Tasmania.

Longworth, N., (2006). Learning Cities, Learning Regions, Learning Communities, Lifelong Learning and Local Government, Routledge.

Ly, K.C., Chen, ZH., Wang, S., Jiang, Y., (2017). The Basel III net stable funding ratio adjustment speed and systemic risk, Journal: Research in International Business and Finance, Vol. 39, Part A, January, 169-182.

Maleki Avaresin, S., Faraji, S., (2015). Study of the status of learning organization in the technical and vocational organization of Urmia city and its adaptation to its entrepreneurial strategies, Journal of Productivity Management, Vol. 9, No. 33, Summer, pp. 193-218.

Manafi, S., Esmail Pour, N., (2015). An Introduction to the Concept of the Learner's Town, The First National Conference on Islamic Architecture, Urban Heritage and Sustainable Development, Bahman, Tehran.

Olivos, P., Santos, A., Martin, S., Canas, M., Gomez-Lazaro, E., Maya, Y., (2016). The relationship between learning styles and motivation to transfer of learning in a vocational training programme, Journal: Suma Psicológica, Vol. 23, Issue 1, 25-32. 
Safania, A. M., (2015). Relationship between learning organization and organizational readiness for change in the experts of the Ministry of Sport and Youth, two editions of management and development of sport, Volume 4, Issue 2, Autumn and Winter, pp. 29-42.

Sarver, R., Akbari, M., Taleshi Anbuhi, M., (2016). Investigating the Relationship between Factors Affecting the Formation of the Learner's Town (Case Study: Bonab City), Geography Quarterly and Environmental Studies, Vol. 5, No. 18, Summer, pp. 103-116.

Schwartz, B., Wasserman, E.A., Robbins, S.J., (2002). Psychology of learning and behavior (5th ed.). New York: Norton.

Shams, Gh., Pardakhtchi, M. H., Maleki, H., (2014). The Effect of Learning Organization on Organizational Performance by Organizational Learning, Quarterly Journal of Educational Thoughts, Vol. 10, No. 3, Autumn, pp. 9-28.

Shikshantar., (1999). The People's Institute for Rethinking Education and Development Udaipur as a Learning City, Draft for Comment of Friday, Udaipur, Rajasthan.

Truong, H., (2016). Integrating learning styles and adaptive e-learning system: Current developments, problems and opportunities, Journal: Computers in Human Behavior, Vol. 55, Part B, 1185-1193.

Trabalho enviado em 21 de março de 2018.

Aceito em 10 de maio de 2018. 